\title{
PERBANDINGAN GAME FRAMEWORK PADA HTML5
}

\author{
${ }^{1}$ Moch. Rizki Romdoni, ${ }^{2}$ Noviana \\ Sekolah Tinggi Teknologi Indonesia, Jurusan Teknik Informatika \\ e-mail : ${ }^{1}$ rizki@sttindonesia.ac.id, ${ }^{2}$ viana201@gmail.com
}

\begin{abstract}
ABSTRAK
Game merupakan aplikasi yang mungkin diminati berbagai kalangan dalam mengisi waktu kosong.Seiring dengan pengembangan game, jumlah orang yang tertarik dalam membuat game juga meningkat. HTML5 merupakan salah satu bahasa pemrograman yang bisa digunakan dalam membuat suatu game. Banyak game framework yang tersedia pada HTML5 yang memungkinkan pengguna kesulitan dalam memilih. Dikarenakan belum adanya penelitian yang membahas tentang perbandingan game framework HTML5, maka penulis mencoba untuk membandingkannya.

Perbandingan game framework meliputi ketersediaan dokumentasi, forum dan performance. Perbandingan dilakukan dengan mengunduh game yang bertema sama dari masing-masing game framework dan kemudian mengukur performance dengan menggunakan Chrome Dev Tools dan Mozilla Dev Tools.

Pada hasil akhir penelitian ini menunjukkan bahwa game framework yang memiliki performance terbaik adalah PixiJS dibandingkan dengan game framework PhaserJS, MelonJS dan KiwiJS.
\end{abstract}

Kata kunci : Game Framework, PhaserJS, PixiJS, MelonJS, KiwiJS.

\section{PENDAHULUAN}

Game merupakan aplikasi pendukung yang mungkin diminati dalam mengisi waktu kosong maupun untuk mengasah kemampuan otak. Banyak juga kalangan-kalangan mulai dari anak balita sampai dengan orang tua sekali pun senang memainkan game. Seiring dengan perkembangan game yang semakin marak maka, jumlah peminat juga meningkat. Selain jumlah pemain yang tinggi, sekarang ini sudah tidak jarang ditemukan banyak orang yang tertarik dalam membuat atau mengembangkan suatu game.

HTML5 biasanya digunakan untuk membuat dan menampilkan isi dari suatu web. Banyak orang belum mengetahui bahwa HTML5 bisa dimanfaatkan sebagai game development tool. Pada bahasa pemrograman ini tidak membutuhkan aplikasi khusus karena hanya menggunakan game framework. Sebagai web developmenttoolHTML5 tidak sulit untuk kita temukan dokumentasi ataupun kajiannya. Akan tetapi, untuk pembahasan HTML5 sebagai game development tool bisa dikatakan sulit untuk menemukan pembahasannya. Ada juga beberapa artikel yang membahas tentang HTML5 dan game frameworknya. Namun artikel yang tersedia masih belum cukup lengkap dan mendalami.

Dengan berkembangnya HTML5 sebagai game development tool, banyak game framework yang dikembangkan mulai dari yang gratis sampai dengan 
yang berbayar. Dimana pada saat memulai pembuatan game pada HTML5 pastinya akan mengalami kesulitan karena harus memilih game framework yang akan digunakan dan banyak waktu yang akan terbuang karena pada akhirnya programmer hanya akan memilih satu game framework saja untuk digunakan. .

Untuk menentukan game framework yang cocok dan layak digunakan dalam mempercepat proses pembuatan game, dapat ditentukan dari bagaimana kemudahan dalam pembelajaran dan pengembangan pada user interfacenya. Kemudian fungsi apa saja dari game framework. Poin penting lainnya adalah game framework yang dipakai memiliki dokumentasi yang dapat dipelajari dan memiliki komunitas yang aktif. Dikarenakan banyak sekali poin yang perlu diperhatikan dalam memilih game framework maka diperlukan adanya suatu cara yang mampu memperkenalkan cara kerja gameframework. Oleh karena itu, penulis mengajukan"Perbandingan GameFramework pada HTML5" sebagai judul skripsi.

\section{KAJIAN PUSTAKA}

\subsection{Definisi Perbandingan}

Dalam Kamus Lengkap Bahasa Indonesia disebutkan bahwa perbandingan berasal dari kata banding yang berarti persamaan, selanjutnya membandingkan mempunyai arti mengadu dua hal untuk diketahui perbandingannya. Perbandingan diartikan sebagai selisih persamaan (Bambang Marhiyanto; 57).

Menurut Sjachran Basah (1994: 7), perbandingan merupakan suatu metode pengkajian atau penyelidikan dengan mengadakan perbandingan di antara dua objek kajian atau lebih untuk menambah dan memperdalam pengetahuan tentang objek yang dikaji. Jadi di dalam perbandingan ini terdapat objek yang hendak diperbandingkan yang sudah diketahui sebelumnya, akan tetapi pengetahuan ini belum tegas dan jelas.

Dari pengertian perbandingan diatas dapat disimpulkan bahwa pengertian perbandingan adalah suatu proses untuk membandingkan dua hal atau lebih untuk mengetahui persamaan dan perbedaanya.

\subsection{DefinisiGame}

Game berasal dari kata bahasa inggris yang memiliki arti dasar "Permainan". Permainan dalam hal ini merujuk pada pengertian "kelincahan intelektual" (intellectual playability).

Games are a type of play activity, contacted in the context of a pretended reality, in which the participant(s) try to achieve at least one arbitrary, nontrivial goal by acting in accordance with rules. Game adalah salah satu jenis aktivitas bermain, yang didalamnya dilakukan dalam konteks berpura pura namun terlihat seperti nyata, yang mana pemainnya memiliki tujuan untuk mendapatkan satu kemenangan serta dilakukan dengan sesuai dengan aturan permainan yang dibuat.

\subsubsection{Tahapan Dalam Membuat Game}


Menurut Samuel Henry dalam bukunya yang berjudul "Panduan Praktis Membuat Game 3D" mengatakan bahwa untuk membuat sebuah game harus melewati beberapa tahapan, secara sederhana tahapan membuat game adalah sebagai berikut: Skenario, Tema/Tujuan, Aturan/Rules, Konflik.

\subsubsection{Elemen Game}

Menurut R. D. Duke (1980), sebagaimana dalam Wachowicz,et al. Terdapat 11 elemen game yang perlu diperhatikan sebagai dasar dalam membuat game yang baik, yaitu: Format, Rules, Policy, Scenario, Events, Roles, Decisions, Levels, Score Model, Indicators, Symbols.

\subsubsection{Jenis-Jenis Game}

Jenis game biasa disebut dengan istilah genre game. Selain berarti jenis, genre juga berarti gaya atau format dari sebuah game. Menurut Henry dalam bukunya yang berjudul "Panduan Praktis Membuat Game 3D" mengatakan format sebuah game bisa murni sebuah genre atau bisa merupakan campuran (hybrid) dari beberapa genre lain. Jenis-jenis game yang ada menurut Henry adalah sebagai berikut: Maze Game, Board Game, Card Game, Battle Card Game, Quiz Game, Puzzle Game, Shoot Them Up, Side Scroller Game, Fighting Game, Racing Game, Turn-Based Strategy, Real-Time Strategy Game, Simulation Video Game, First Person Shooter, First Person Shooter 3D, Third person 3D Games, Role Playing Game, Adventure Game, Educational and Edutaiment, Game sports.

Berdasarkan jenis platform-nya game dikategorikan menjadi: Arcade, Console, Computer Games, Online Games, Handheld Games, Mobile Games, Tabletop.

\subsection{Framework}

Framework adalah kerangka kerja. Framework juga dapat diartikan sebagai kumpulan script (terutama class dan function) yang dapat membantu developer/programmer dalam menangani berbagai masalah-masalah dalam pemrograman seperti koneksi ke database, pemanggilan variabel, file dan lainlain.

Framework mirip dengan application programming interface (API), walaupun secara teknik API sudah termasuk dalam framework. Seperti namanya framework berfungsi sebagai suatu fondasi untuk pemrograman, sementara API menyajikan akses ke elemen-elemen yang didukung oleh framework. Framework juga meliputi code libraries, compiler, dan program lainnya yang digunakan pada proses pengembangan perangkat lunak.

Ada beberapa hal yang harus di pertimbangkan dalam memilih framework: Pertama adalah dokumentasi dari framework itu sendiri. Berikutnya kesesuaian framework tersebut dengan aplikasi apa yang hendak kita kembangkan. Selanjutnya adalah memperhatikan standar-standar framework yang ada. Semakin banyak ibid yang di support oleh framework tersebut semakin baik

\subsection{Game Framework}


Game framework is not a game engine. A game engine is more like a finished piece of code that you would use as a black box to make a game; It's more about instattiation and configuration than software engineering. An engine has functions that you use, so you don't have to write the code yourself. A game framework, on the other hand, is used to help you organized your code and game functions. It can start out fairly but can be expanded and changed as your games get more complicated.

Game framework bukan game engine. Game engine terlihat seperti kode yang sudah lengkap dan akan digunakan sebagai black box untuk membuat game; sedangkan game framework lebih ke instansiansi dan konfigurasi dibandingkan dengan software engineering (rekayasa perangkat lunak). Game framework pada pengertian lainnya adalah sesuatu yang digunakan untuk mebantu dalam mengatur/mengorganisirkan kode dan function pada game. Dimana game framework bisa dimulai dengan biasa saja tapi dapat dikembangkan dan diubah seiring dengan tingkat kerumitan pada game.

\subsection{Perangkat Lunak Yang Digunakan}

\subsubsection{HTML5}

Hyper Text Mark-up Language (HTML) adalah bahasa yang digunakan untuk membuat suatu halaman web dan menampilkan berbagai informasi di dalam sebuah browser internet. Bermula dari sebuah bahasa yang sebelumnya banyak digunakan secara luas untuk menampilkan SGML (Standard GeneralizedMarkup Language), HTML adalah sebuah standar yang digunakan secara luas untik menampilkan halaman web. HTML saat ini merupakan standar Internet yang didefinisikan dan dikendalikan penggunaanya oleh World Wide Consortium (W3C).

When you add an $X$ in front of HTML, you get XHTML, a reworked version of HTML based on the eXtensible Markup Language (XML). XML was designed to work and behave well with computers, software, and the Internet. Bila menambahkan X di depan HTML, maka akan mendapatkan XHTML, yaitu sebuah versi yang dikerjakan ulang oleh HTML berdasarkan eXtensible Markup Language (XML).XML dirancang untuk dapat bekerja baik terhadap komputer, perangkat lunak, dan internet.

HTML5 already appears to be succeeding where XHTML did not. Even though the standard is still under construction, HTML5 is widely adopted and used on the web today.HTML5 sudah tampak sukses yang mana sebelumnya tidak pada XHTML. Meskipun standarnya masih dalam proses pengembangan, HTML5 banyak digunakan dan digunakan di web saat ini.

\subsubsection{PhaserJS}

Phaser is a fast, free, and fun open source HTML5 game framework. It uses a custom build of Pixi.js for WebGL and Canvas rendering, and supports desktop and mobile web browsers. Games can be compiled to iOS, Android and native desktop apps via 3rd party tools. 
Phaser merupakan game framework open source pada HTML5 yang cepat, gratis dan menyenangkan. Phaser menggunakan custom build dari PixiJS untuk WebGL dan Canvas rendering, dan mendukung penggunaan pada desktop maupun web browsers. Games dapat dikompilasi ke iOS, Android dan aplikasi desktop melalui tools pihak ke-3.

\subsubsection{PixiJS}

PixiJS is a rendering library that will allow you to create rich, interactive graphics, cross platform applications, and games without having to dive into the WebGL API or deal with browser and device compatibility. PixiJS has full WebGL support and seamlessly falls back to HTML5's canvas if needed.

PixiJS adalah rendering library yang memungkinkanuntuk membuat grafik yang interaktif,aplikasi multi platform, dan permainan tanpa harus mengerti tentang WebGL API atau menangani kompatibilitas browser danperangkat. PixiJS memiliki dukungan penuh terhadap WebGL dan dengan cepatkembalike kanvas HTML5 jika diperlukan.

\subsubsection{MelonJS}

melonJS is an open source HTML5 game engine that empowers developers and designers to focus on content. The framework provides a collection of composable entities and support for a number of third-party tools.

melonJS merupakan open source dari game engime HTML5 yang memberikan developers dan desainer untuk fokus pada isinya (content). Framework ini menyediakan berbagai entitas yang dapat diubah entitasnya dan mendukung tools dari pihak ketiga.

\subsubsection{KiwiJS}

Kiwi.js is the worlds easiest to use Open Source HTML5 game framework for making both mobile and desktop HTML5 browser games. Our focus is blazingly fast WebGL rendering and complimentary tools to make professional quality serious games. We use CocoonJS for publishing games and App creation.

KiwiJS merupakan game framework termudah di dunia untuk digunakan sebagai game framework HTML5 yang bersifat open source untuk membuat game browser pada mobile maupun desktop. GameFramework ini berfokus pada rendering WebGL yang cepat serta menyediakan tools yang gratis untuk menciptakan game yang berkualitas dan profesional. KiwiJS menggunakan CocoonJS untuk menerbitkan game dan pembuatan App.

\subsubsection{XAMPP}

$X A M P P$ adalah sebuah software yang berfungsi untuk menjalankan website berbasis $P H P$ dan menggunakan pengolah data $M Y S Q L$ di komputer lokal. XAMPP berperan sebagai server web pada komputer anda.Nama XAMPP merupakan singkatan dari X (empat sistem operasi), Apache, MySQL, PHP dan Perl. Program ini tersedia di bawah GNU General Public License dan bebas, adalah mudah untuk menggunakan web server yang dapat melayani tampilan halaman web yang dinamis. 


\subsubsection{Adobe Photoshop CS3}

Adobe Photoshop adalah perangkat lunak editor citra buatan Adobe Systems yang dikhususkan untuk pengeditan foto/gambar dan pembuatan efek. Perangkat lunak ini banyak digunakan oleh fotografer digital dan perusahaan iklan sehingga dianggap sebagai pemimpin pasar (market leader) untuk perangkat lunak pengolah gambar/foto, dan, bersama Adobe Acrobat, dianggap sebagai produk terbaik yang pernah diproduksi oleh Adobe Systems.

\subsubsection{Microsoft Office Visio 2007}

Microsoft visio (atau sering disebut visio) adalah sebuah program aplikasi computer yang sering digunakan untuk membuat diagram, diagram aliran (flowchart), brainstorm, dan skema jaringan yang dirilis oleh Microsoft Corporation. Aplikasi ini menggunakan grafik vector untuk membuat diagram-diagramnya.

\section{METODOLOGI PENELITIAN}

Metode pengembangan sistem yang digunakan pada penelitian ini adalah metodologi Multimedia Development Life Cycle (MDLC). Menurut Sutopo (2003), yang berpendapat bahwa metode pengembangan multimedia terdiri dari 6 tahapan, yaitu concept, design, material collecting, assembly, testing, distribution seperti gambar dibawah ini:

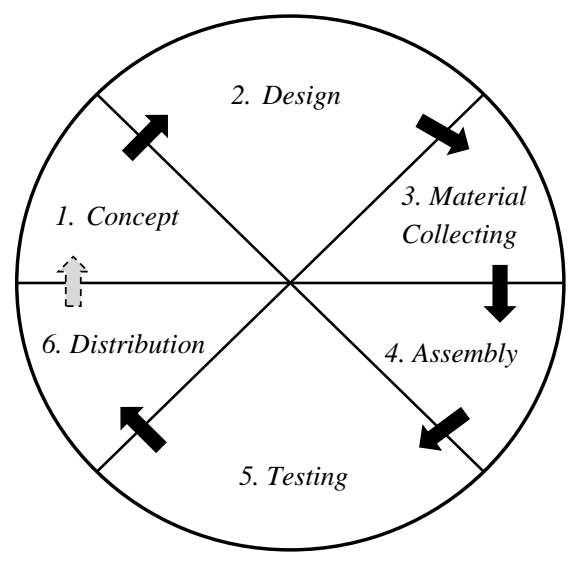

\section{Gambar 1.2 Multimedia Development Life Cycle (MDLC)}

Adapun tahapan-tahapan pengembangan multimedia pada saat membuat contoh game yang diuji sebagai berikut:

1. Concept, dalam tahapan ini, kegiatan yang dilakukan yaitu:

1. Menentukan jenis game yang akan dibuat yaitu game casual.

2. Menentukan jumlah player pada game.

3. Menentukan alur dari suatu game.

2. Design, pada tahap ini, hal yang akan dikerjakan meliputi:

1. Pembuatan flowchart game.

2. Menentukan gambar atau asset apa saja yang diperlukan dalam game. 
3. Material Collecting, Pengumpulan materi adalah tahap pengumpulan bahan yang sesuai dengan kebutuhan yang dikerjakan. Kemudian yang dilakukan dalam tahap ini adalah mencari dokumentasi - dokumentasi game framework.

4. Assembly, Tahap assembly adalah adalah tahap pembuatan semua objek atau bahan multimedia. Pembuatan aplikasi didasarkan pada tahap design. Dalam tahapan ini membuat game dengan menggunakan game framework.

5. Testing, Tahap pengujian setelah menyelesaikan tahap pembuatan (assembly) dengan menjalankan aplikasi dan melihat apakah ada kesalahan atau tidak. Pada tahap ini akan menguji apakah game dapat dijalankan sesuai dengan game framework yang dibuat.

6. Distribution, Pada tahap ini aplikasi akan disimpan dalam suatu media penyimpanan. Tahap ini dilakukan jika game yang dibuat sudah lengkap yaitu dapat didistribusikan pada google play store.

\section{HASIL DAN PEMBAHASAN}

Analisis sistem merupakan penguraian dari suatu sistem informasi yang utuh kedalam bagian-bagian komponennya dengan maksud untuk dan mengevaluasi dan mengetahui bagaimana asal usul sistem yang akan ditelti dan dibangun. Perancangan game dengan beberapa game framework sebagai berikut:

\subsection{Storyline dalam merancang sistem}

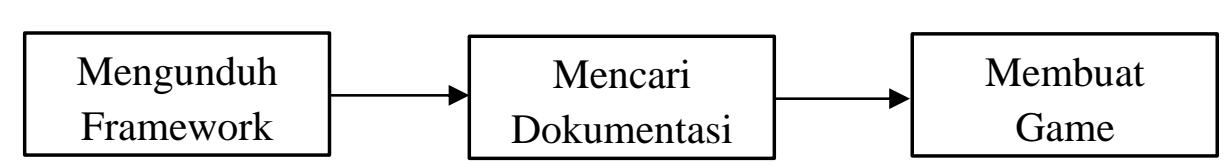

Gambar 1 Storyline dalam merancang system

\subsection{Tahap merancang Game dengan PhaserJS}

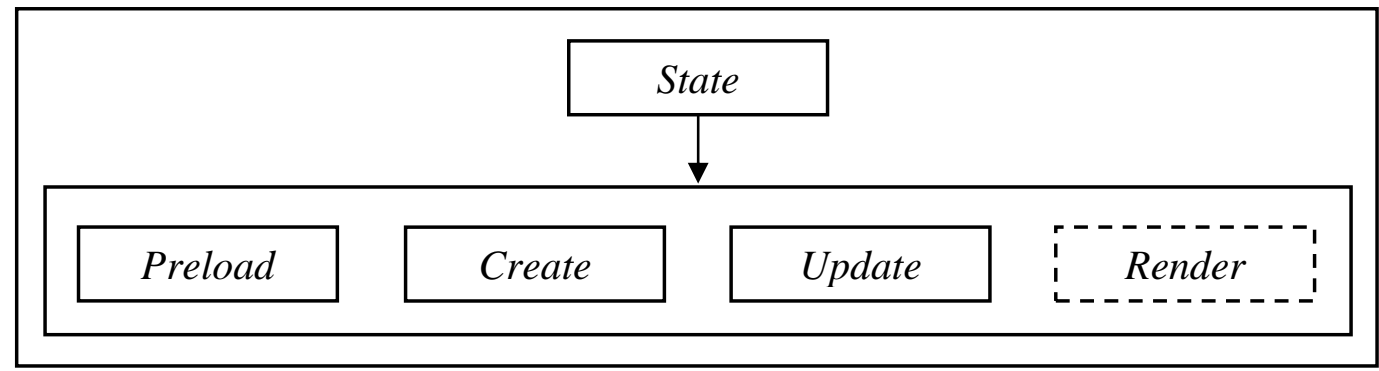

Gambar 2 Tahap merancang Game dengan PhaserJS 
4.3 Tahap merancang Game dengan PixiJS

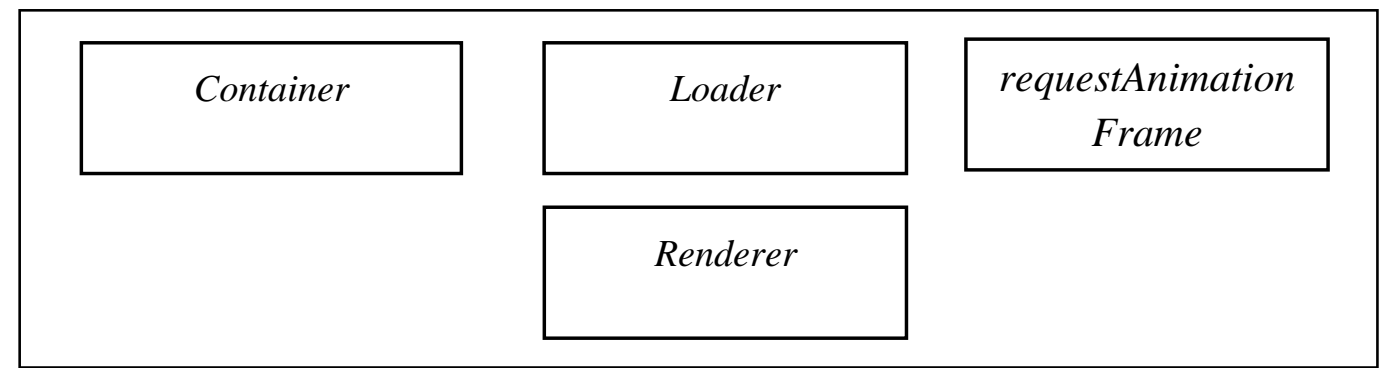

Gambar 3 Tahap merancang Game dengan PixiJS

\subsection{Tahap merancang Game dengan MelonJS}

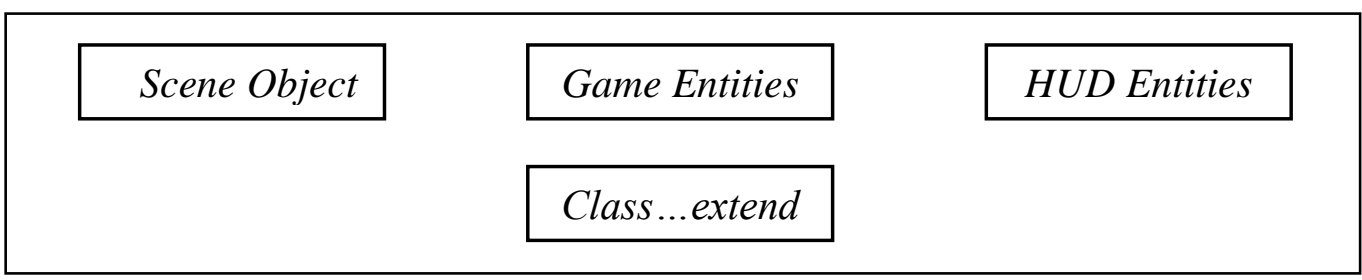

Gambar 4 Tahap merancang Game dengan MelonJS

\subsection{Tahap merancang Game dengan KiwiJS}

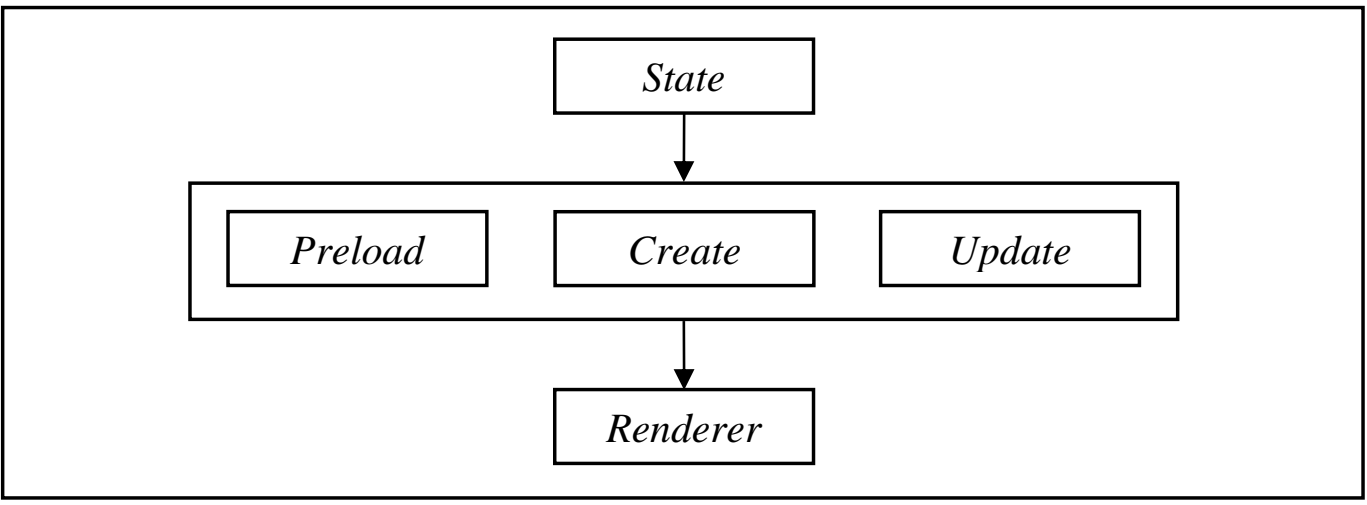

Gambar 5 Tahap merancang Game dengan KiwiJS 


\section{Pengujian game dengan PhaserJS}

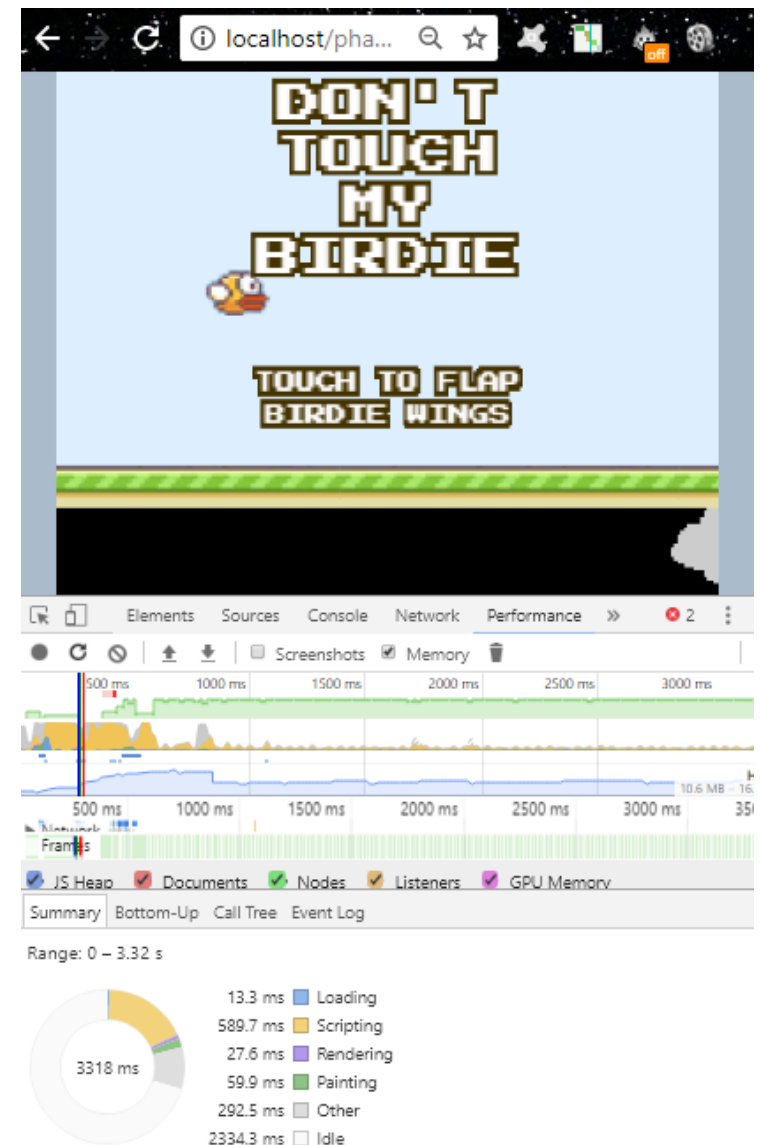

Gambar 6Performance Flappy Bird (PhaserJS) dengan Chrome Dev Tools

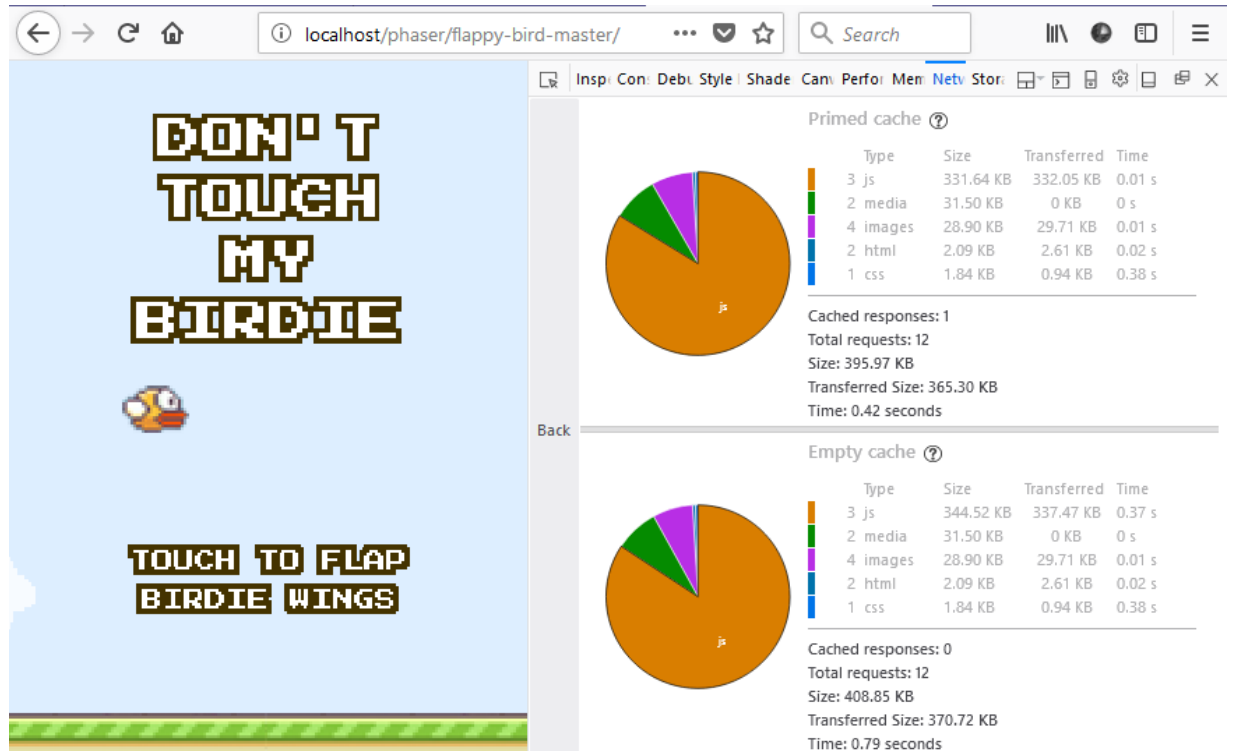

Gambar 7 Performance Flappy Bird (PhaserJS)denganMozilla Dev Tools 


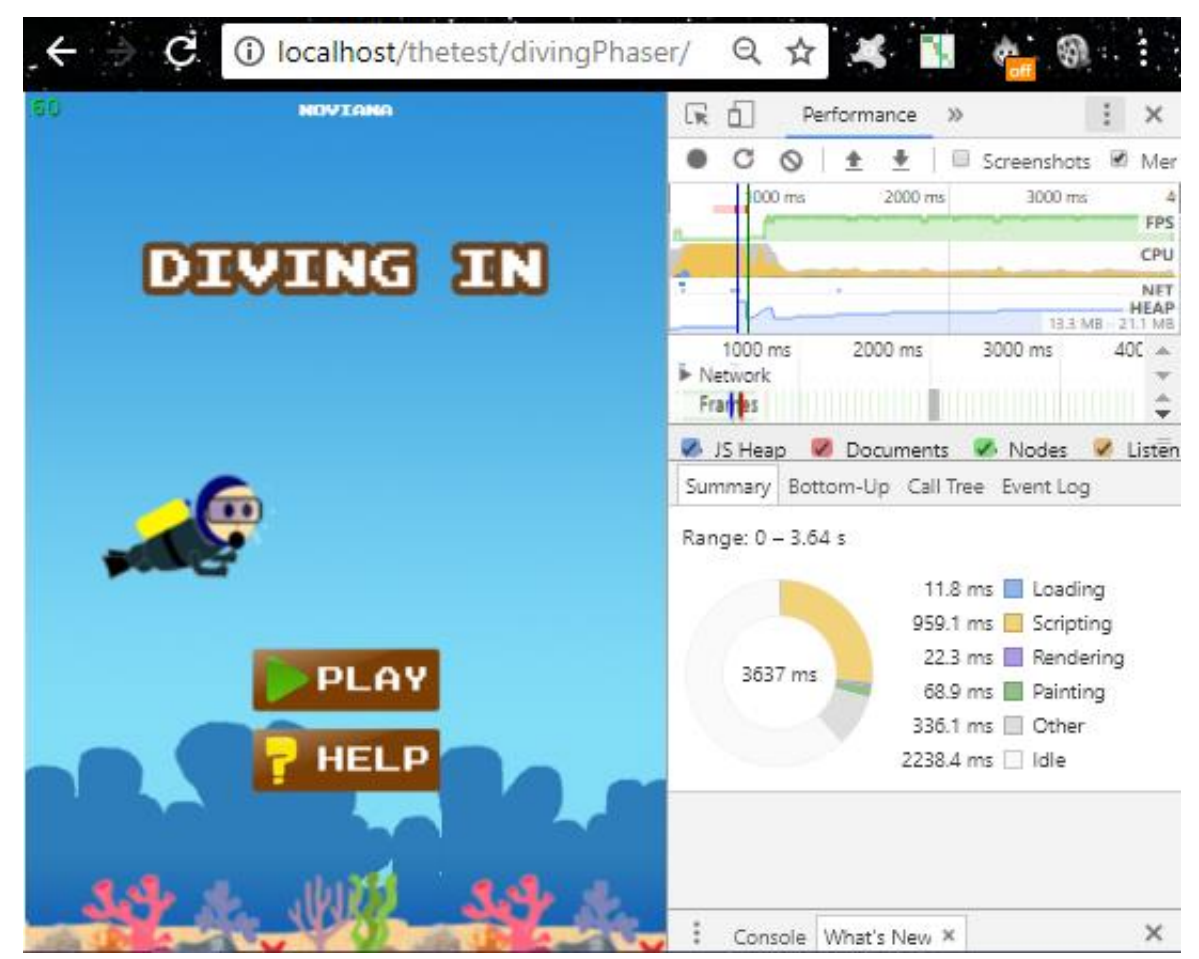

Gambar 8 Performance Diving In (PhaserJS)dengan Chrome Dev Tools

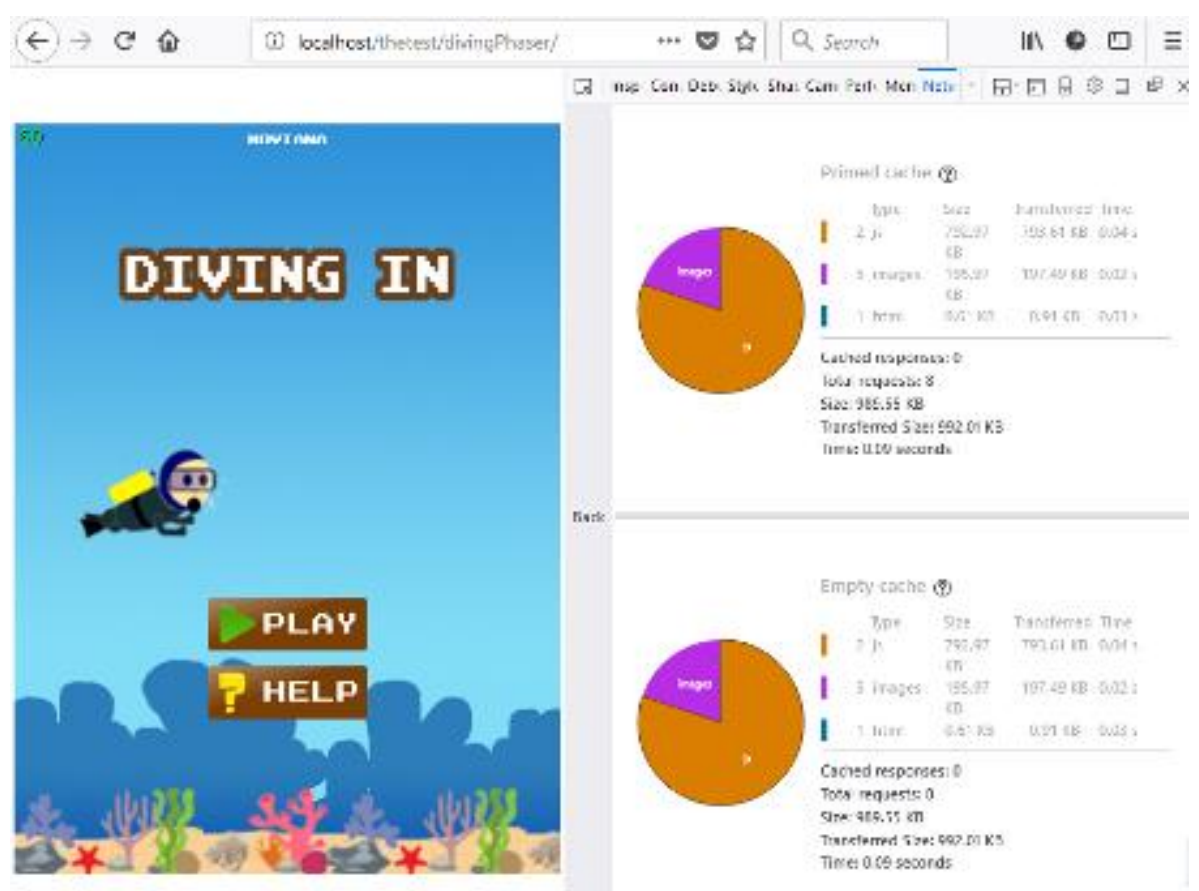

Gambar 9 Performance Diving In (PhaserJS)dengan Mozilla Dev Tools 


\subsection{Pengujian game dengan PixiJS}

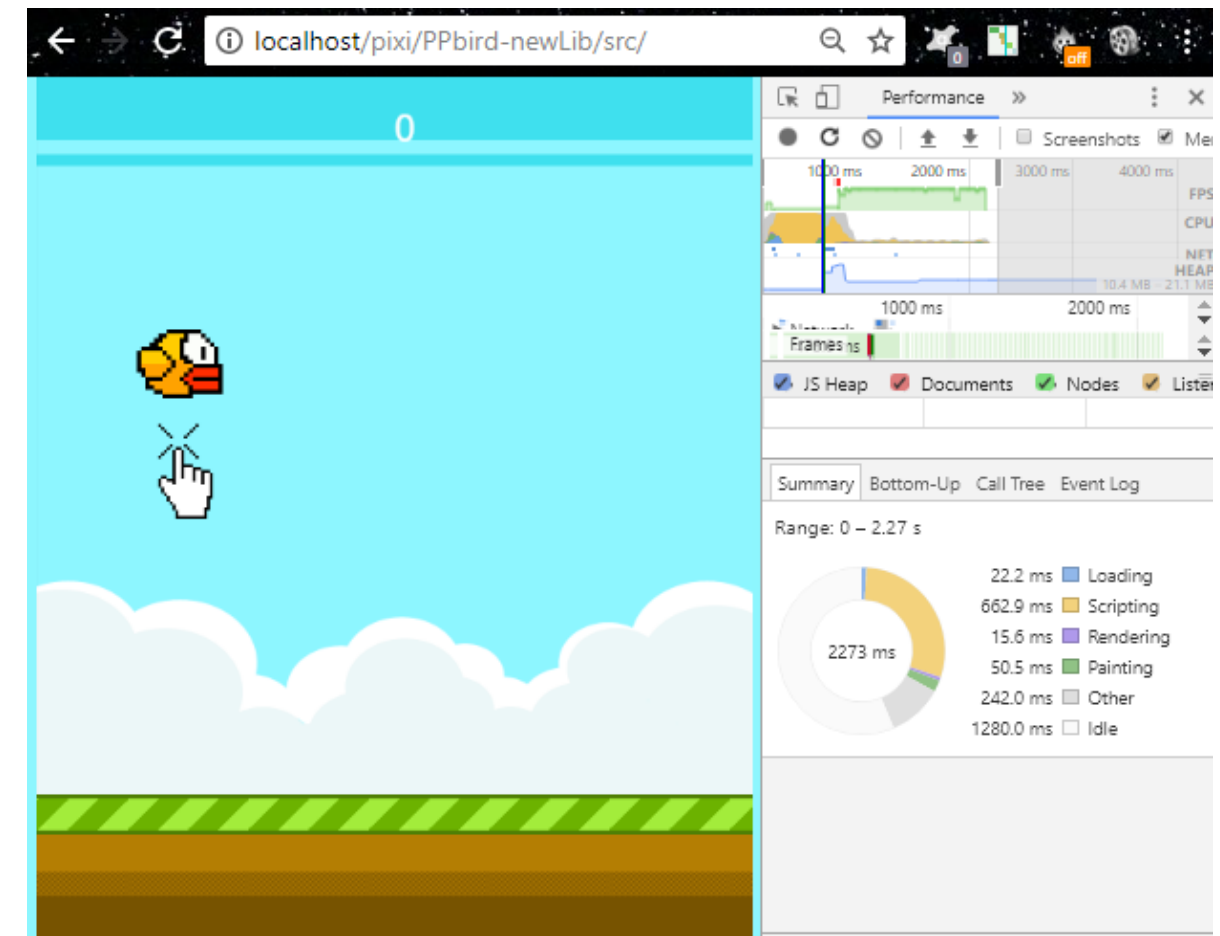

Gambar 10 Performance Flappy Bird (PixiJS)dengan Chrome Dev Tools

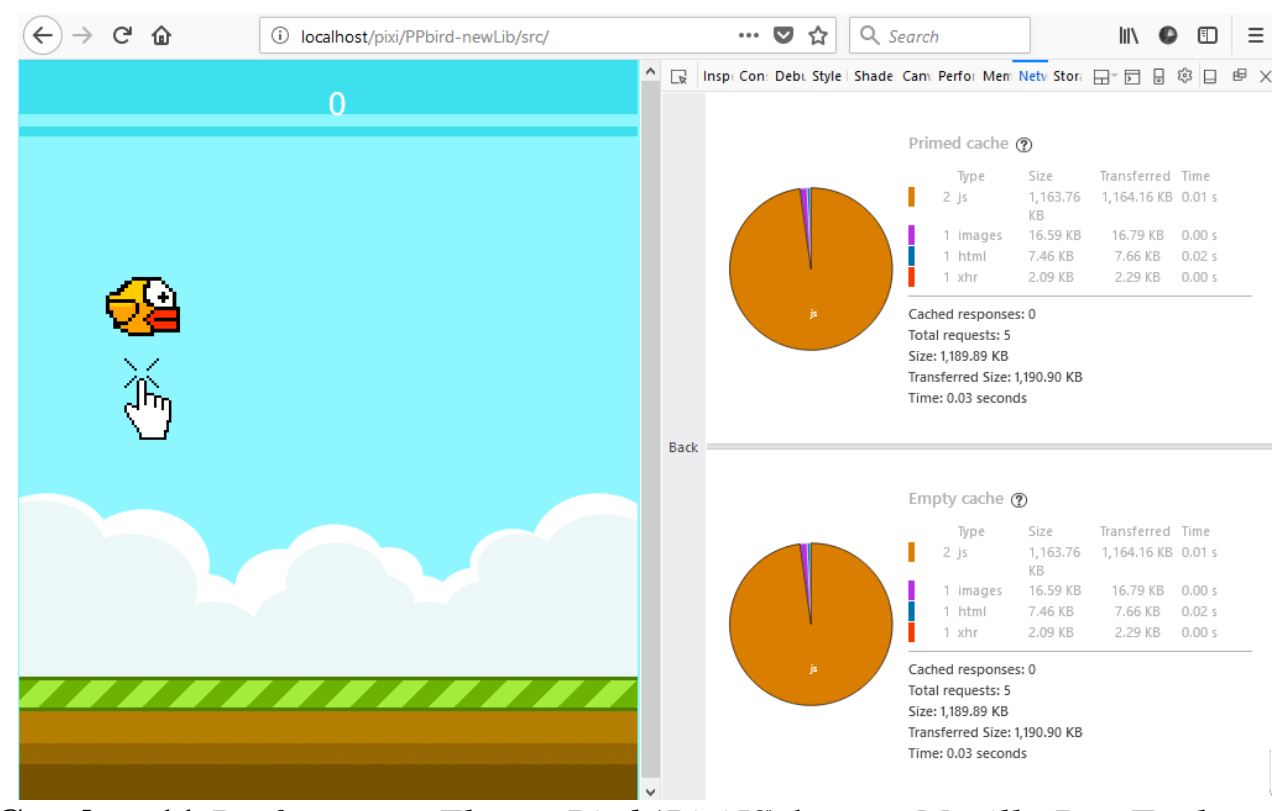

Gambar 11 Performance Flappy Bird (PixiJS)dengan Mozilla Dev Tools 


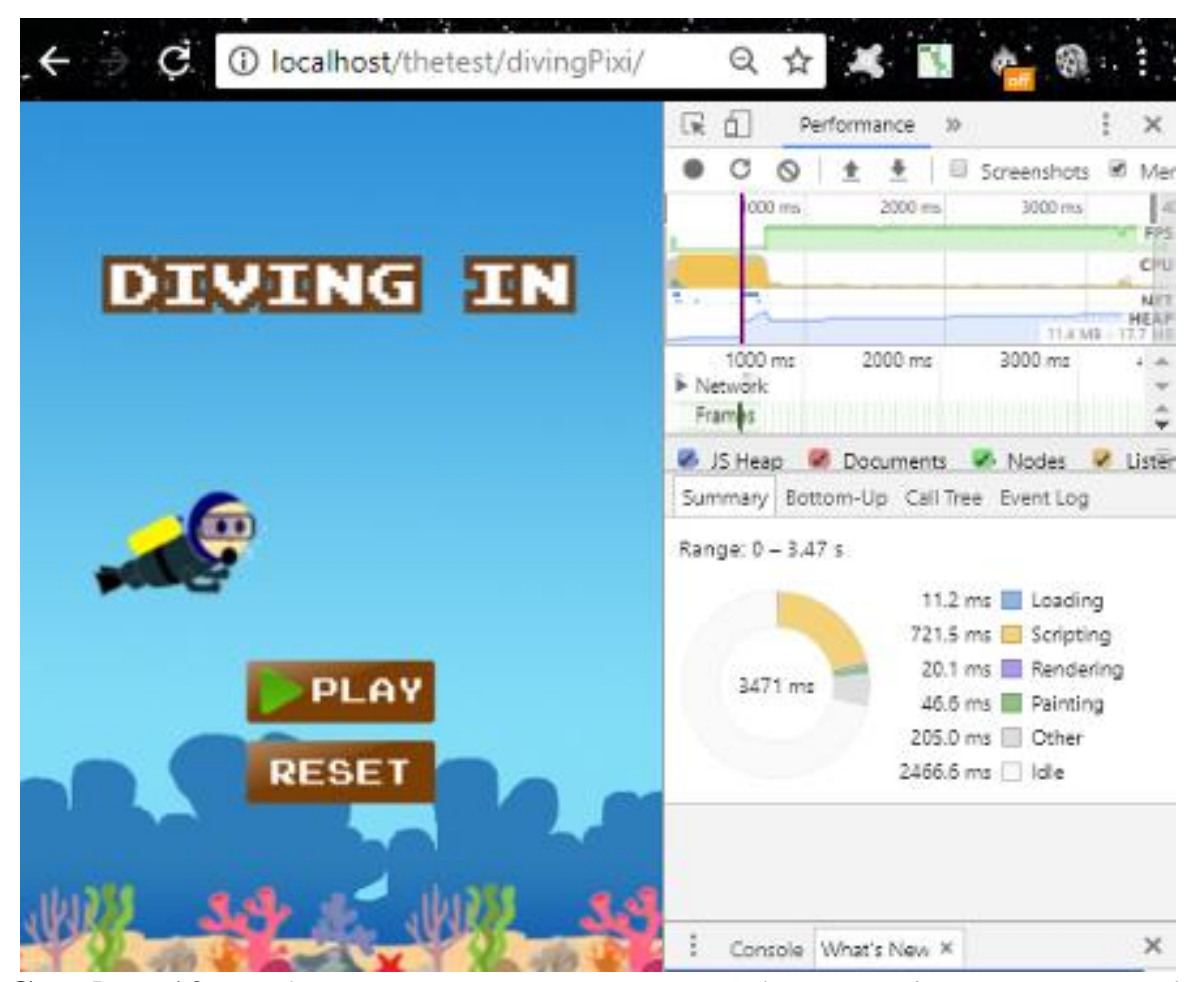

Gambar 12 Performance Diving In (PixiJS)dengan Chrome Dev Tools

\subsection{Pengujian game dengan MelonJS}

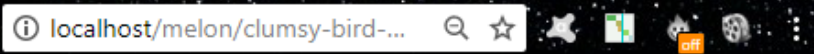

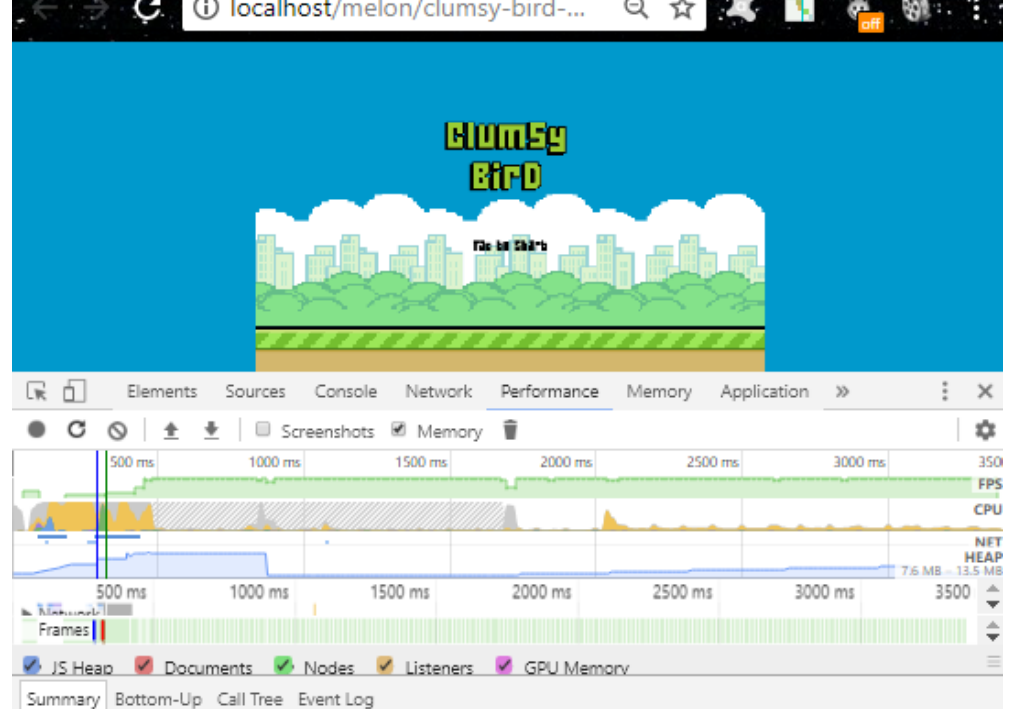

Summary Bottom-Up Call Tree Event Log

Range: $0-3.41 \mathrm{~s}$

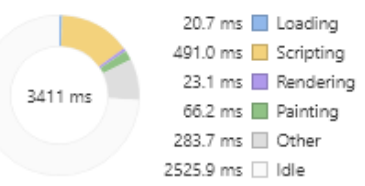

Gambar 13 Performance Flappy Bird (MelonJS)dengan Chrome Dev Tools 


\subsection{Hasil Perbandingan antar Game Framework HTML5}

Tabel 1 Hasil Perbandingan

\begin{tabular}{|c|c|c|c|c|}
\hline & PhaserJS & PixiJS & MelonJS & KiwiJS \\
\hline Dokumentasi & Ada & Ada & Ada & Ada \\
\hline $\begin{array}{l}\text { Forum \& Diskusi } \\
\text { (berdasarkan } \\
\text { html5gamedevs.com) }\end{array}$ & $\begin{array}{l}61,136 \\
\text { postingan }\end{array}$ & $\begin{array}{l}13,478 \\
\text { postingan }\end{array}$ & $\begin{array}{l}581 \\
\text { postingan }\end{array}$ & $\begin{array}{l}33 \\
\text { postingan }\end{array}$ \\
\hline \multicolumn{5}{|c|}{ Perfomance game Flappy Bird berdasarkan Chrome DevTools } \\
\hline Loading & $13.3 \mathrm{~ms}$ & $22.2 \mathrm{~ms}$ & $20.7 \mathrm{~ms}$ & $14.5 \mathrm{~ms}$ \\
\hline Scripting & $589.7 \mathrm{~ms}$ & $662.9 \mathrm{~ms}$ & $491 \mathrm{~ms}$ & $335.6 \mathrm{~ms}$ \\
\hline Rendering & $27.6 \mathrm{~ms}$ & $15.6 \mathrm{~ms}$ & $23.1 \mathrm{~ms}$ & $19.9 \mathrm{~ms}$ \\
\hline Painting & $46.2 \mathrm{~ms}$ & $50.5 \mathrm{~ms}$ & $66.2 \mathrm{~ms}$ & $84.6 \mathrm{~ms}$ \\
\hline Other & $59.9 \mathrm{~ms}$ & $242 \mathrm{~ms}$ & $283.7 \mathrm{~ms}$ & $252.8 \mathrm{~ms}$ \\
\hline Idle & $2343.3 \mathrm{~ms}$ & $1280 \mathrm{~ms}$ & $2525.9 \mathrm{~ms}$ & $2762.5 \mathrm{~ms}$ \\
\hline Total & $3318 \mathrm{~ms}$ & $2273 \mathrm{~ms}$ & $3411 \mathrm{~ms}$ & $3471 \mathrm{~ms}$ \\
\hline \multicolumn{5}{|c|}{ Perfomance game Diving In berdasarkan Chrome DevTools } \\
\hline Loading & $11.8 \mathrm{~ms}$ & $11.2 \mathrm{~ms}$ & $30.1 \mathrm{~ms}$ & $12.6 \mathrm{~ms}$ \\
\hline Scripting & $959.1 \mathrm{~ms}$ & $721.5 \mathrm{~ms}$ & $664 \mathrm{~ms}$ & $584.8 \mathrm{~ms}$ \\
\hline Rendering & $22.3 \mathrm{~ms}$ & $20.1 \mathrm{~ms}$ & $28.1 \mathrm{~ms}$ & $27.9 \mathrm{~ms}$ \\
\hline Painting & $68.9 \mathrm{~ms}$ & $46.6 \mathrm{~ms}$ & $112 \mathrm{~ms}$ & $146.4 \mathrm{~ms}$ \\
\hline
\end{tabular}




\begin{tabular}{|l|l|l|l|l|}
\hline Other & $336.1 \mathrm{~ms}$ & $205 \mathrm{~ms}$ & $340.5 \mathrm{~ms}$ & $392.9 \mathrm{~ms}$ \\
\hline Idle & $2238.4 \mathrm{~ms}$ & $2466.6 \mathrm{~ms}$ & $2474.1 \mathrm{~ms}$ & $2683.7 \mathrm{~ms}$ \\
\hline Total & $3637 \mathrm{~ms}$ & $3471 \mathrm{~ms}$ & $3649 \mathrm{~ms}$ & $3848 \mathrm{~ms}$ \\
\hline Perfomance game Flappy Bird berdasarkan Firefox DevTools \\
\hline Transferred Size & $365.30 \mathrm{~KB}$ & $\begin{array}{l}1190.90 \\
\text { KB }\end{array}$ & 1701.73 & $720.44 \mathrm{~KB}$ \\
\hline Time & $420 \mathrm{~ms}$ & $30 \mathrm{~ms}$ & $130 \mathrm{~ms}$ & $100 \mathrm{~ms}$ \\
\hline Perfomance game Diving In berdasarkan Firefox DevTools & KB \\
\hline Transferred Size & $989.55 \mathrm{~KB}$ & $\begin{array}{l}1403.58 \\
\text { KB }\end{array}$ & $454.43 \mathrm{~KB}$ & $\begin{array}{l}1,641.07 \\
\text { KB }\end{array}$ \\
\hline $\begin{array}{l}|l| \\
\text { Time }\end{array}$ & $90 \mathrm{~ms}$ & $70 \mathrm{~ms}$ & $120 \mathrm{~ms}$ & $360 \mathrm{~ms}$ \\
\hline
\end{tabular}

\section{KESIMPULAN}

Berdasarkan hasil yang didapatkan dalam analisis perbandingan game framework pada HTML5, penulis menyimpulkan bahwa:

1. Game framework yang mempunyai tingkat performance terbaikdiantara PhaserJS, PixiJS, MelonJS dan KiwiJS adalah gameframework PixiJS dengan mempunyai waktu tercepat ketika memuat game pada Google Chrome maupun Mozilla Firefox.

2. Game framework MelonJS merupakan game framework yang sulit untuk digunakan karena pada game yang diuji masih banyak komponen yang belum bisa dilengkapi.

3. Pengguna terbanyak dari game framework yang dibandingkan, Jika dilihat dari postingan dari forum, PhaserJS memiliki jumlah postingan terbanyak yang memungkinkan jumlah pengguna framework terbanyak pada saat ini. Selain itu, jumlah postingan atau diskusi yang paling sedikit adalah game framework KiwiJS.

4. Dari hasil tingkat performance, KiwiJS memiliki tingkat performance yang paling rendah pada .

5. PixiJS juga mempunyai proses rendering tercepat dibandingkan dengan game framework PhaserJS, MelonJS dan KiwiJS.

6. Jika menggunakan Mozilla Firefox sebagai platform dalam menjalankan game, PhaserJS mempunyai transferred size terkecil diantara game framework yang dibandingkan lainnya. 
Dari kesimpulan di atas, penulis mengajukan beberapa, yaitu:

1. Diharapkan game framework bisa dibandingkan dari sisi yang lainnya selain performance.

2. Diharapkan user yang ingin menggunakan game framework ini, setidaknya harus menguasai dasar-dasar algoritma pemrograman, bahasa HTML5 dan JavaScript.

3. Diharapkan user mempelajari dokumentasi terlebih dahulu sebelum memulai penggunaan game framework.

\section{DAFTAR PUSTAKA}

Adams, Ernest, Fundamentals of Game Design Third Edition, New Riders, United States of America, 2014.

Asmiatun, Siti, Astrid Novita Sari, Belajar Membuat Game 2D dan 3D menggunakan Unity, Deepublish, Yogyakarta, 2017.

Faizal, M, Elvianna, Dedy Jauhari, Ricak Agus Setiawan, Moch Rizki Romdoni, Buku Panduan Penulisan Laporan Kerja Praktek Dan Skripsi Sekolah Tinggi Teknologi Indonesia, Tanjungpinang, 2014.

Fulton, Jeff dan Steve Fulton, The Essential Guide To Flash Games Building Interactive Entertainment with ActionScript, Friends of ED, United States of America, 2010.

Novak, Jeannie, Game Development Essentials Third Edition, Delmar; Cengange Learning, USA, 2012.

Prayitno, Indram, Kupas Tuntas Malware, Elex Media Komputindo, Jakarta, 2006.

Sinarmata, Janner, Rekayasa Perangkat Lunak, CV. Andi OFFSET, Yogyakarta, 2010.

Sutopo, Ariesto Hadi, Multimedia Interaktif dengan Flash, Graha Ilmu, Yogyakarta, 2003.

Tittel, El, Chris Minnick, Beginning HTML5 and CSS3 For Dummies 1st Edition, John Wiley \& Sons, Hoboken, 2013.

Wicaksono, Yogi, Membangun Bisnis Online dengan Mambo, Elex Media Komputindo, Jakarta, 2008.

Marzuki, Fandri Chandra, Game Berbasis Adventure Sebagai Pendukung Pembelajaran Pengenalan Kata Bahasa Inggris Untuk Anak Usia Dini, Universitas Lampung, Bandar Lampung.

WH, Sri Rejeki, Perbandingan Pelaksanaan Program Keluarga Berencana Di Era Desentralisasi Di Kabupaten Lampung Tengah Dan Lampung Barat, Universitas Lampung, Bandar Lampung, 2015. 
AdobePhotoshop, [Online] Available:

ttps://id.wikipedia.org/wiki/Adobe_Photoshop.

Daftar Game Framework, [Online] Available: https://html5gameengine.com/.

Definisi Framework, [Online] Available:

https://sheteeguh.wordpress.com/materi-matematika/framework-php/.

Definisi Framework, [Online] Available:

http://techterms.com/definition/framework.

Definisi Framework, [Online] Available: http://www.dcc-dp.org/berita498-

pengertian-framework-dalam-pemrograman.html.

Dokumentasi KiwiJS, [Online] Available: http://www.kiwijs.org/api/.

Dokumentasi MelonJS, [Online] Available:

http://melonjs.github.io/melonJS/docs/.

Dokumentasi PhaserJS, [Online] Available: http://phaser.io/docs/2.6.2/index.

Dokumentasi PixiJS, [Online] Available:

http://pixijs.download/release/docs/index.html.

Fitur KiwiJS, [Online] Available: http://www.kiwijs.org/.

Fitur MelonJS, [Online] Available: http://melonjs.org/index.html\#getting-

started.

Fitur PhaserJS, [Online] Available: https://phaser.io.

Fitur PixiJS, [Online] Available: http://www.pixijs.com/\#features-list.

Forum Game Framework, [Online] Available:

http://www.html5gamedevs.com/forum/13-frameworks/.

Game Clumsy Bird, [Online] Available:

https://github.com/ellisonleao/clumsy-bird.

Game Distance Flyer, [Online] Available:

http://www.kiwijs.org/blueprints/distance-flyer-blueprint/.

Game Don't Touch My Birdie, [Online] Available:

https://github.com/uralozden/flappy-bird/.

Game Copy Flappy Bird, [Online] Available:

https://github.com/fishenal/PPbird.

KiwiJS, [Online] Available: http://www.kiwijs.org/documentation/.

PhaserJS, [Online] Available: https://github.com/photonstorm/phaser.

PixiJS, [Online] Available: http://pixijs.download/release/docs/index.html .

MelonJS, [Online] Available: http://melonjs.org/.

$X A M P P$, [Online] Available: https://id.wikipedia.org/wiki/XAMPP. 